\title{
Formation of the Psychotherapy Service of the FMUSP Psychiatry Institute: a brief historiographical approach
}

\author{
Gustavo Gil Alarcão ${ }^{1}$, André Mota ${ }^{2}$, Francisco Lotufo Neto ${ }^{3}$
}

Alarão GG, Mota A, Lotufo Neto F. Formação do Serviço de Psicoterapia do Instituto de Psiquiatria FMUSP: uma breve leitura historiográfica / Formation of Psychoterapy Service of FMUSP Psychiatry Institute: a brief historiographical approach. Rev Med (São Paulo). 2016 July-Aug.;95(Special Issue 2):93-100.

\begin{abstract}
This article aims to present the activities of Service of Psychotherapy of the Institute of Psychiatry of the Clinical Hospital of the FMUSP (IPQ) from a historiographical perspective, positioning it critically in the scenario of different modalities of care in mental health within the IPQ between 1962 and 1965. Psychotherapy Service involves care of patients in psychotherapy, teaching and knowledge transfer as well as research in the scientific domain. It has also played an important role within the various IPQ services and groups including the debates of the "psi field" throughout its fifty years of existence. We seek to identify how the 60 s can be considered an important historical mark. The proximity between psychiatry and psychoanalysis enabled the development of the notion of psychodynamics, from which the founding work in group psychotherapy emerged. The IPQ represented an important professional training center in the city. Supported by the notions of complexity and pluralism that would mark the future of mental health, this article demonstrates the importance of Psychotherapy Service in the historical process of this field.
\end{abstract}

KEYWORDS: Psychotherapy; Psychotherapy/history; Psychoanalysis; Psychoanalysis/history; Hospitals, psychiatric/ history; Mental health/history.
RESUMO: O presente artigo tem o objetivo de apresentar as atividades do Serviço de Psicoterapia do Instituto de Psiquiatria do HC FMUSP (IPQ) em um recorte historiográfico, posicionando-o criticamente no cenário das diferentes modalidades de atendimento em saude mental no âmbito do IPQ entre 1962-1965. Responsável pelo atendimento de pacientes em psicoterapia, pelo ensino e transmissão de conhecimentos e também por pesquisa e investigação científica, o Serviço de Psicoterapia cumpre um importante papel dentro dos vários serviços e grupos do IPQ, bem como se insere nos debates do "campo psi" ao longo de seus cinquenta anos de existência. Buscamos identificar como a década de 60 foi um importante marco histórico. A proximidade entre psiquiatria e psicanálise permitiu o desenvolvimento da noção de psicodinâmica. Surgiam os primeiros trabalhos em psicoterapia de grupos. O IPQ representava um importante centro de formação profissional na cidade. Apoiados nas noções de complexidade e pluralismo, que marcariam o futuro da saude mental, o artigo demonstra a importância do Serviço de Psicoterapia no processo histórico desse campo.

DESCRITORES: Psicoterapia; Psicoterapia/história; Psicanálise; Psicanálise/história; Hospitais psiquiátricos/história; Saúde mental/história.

1. Psychiatrist and psychoanalyst, associate member of the Brazilian Society of Psychoanalysis of São Paulo, assistant of the USP IPQ Psychotherapy Service and post-graduate student of the FMUSP Department of Preventive Medicine.

2. Historian and Coordinator of the Carlos da Silva Lacaz Museum of the FMUSP. Professor of the Graduate Program in Preventive Medicine Professor of the Subject MSP 0678 Medicine and Humanities.

3. Associate Professor of the Department of Psychiatry of the University of São Paulo's Faculty of Medicine (FMUSP).

Mailing address Gustavo Gil Alarcão. Rua Dr. Ovídio Pires de Campos 785, $4^{\circ}$ andar, Serviço de Psicoterapia, São Paulo, SP, CEP 01060-970, tel. 2661-6576. gustavogilalarcao@yahoo.com.br 


\section{INTRODUCTION}

$\mathrm{T}$ his article aims to present the activities of the Psychotherapy Service of the Psychiatry Institute (IPQ) of the Clinical Hospital of the University of São Paulo's Faculty of Medicine (CH-FMUSP) from a historiographical perspective, positioning it critically in the scenario of different care modalities in mental health of human beings within the IPQ between 1962 and 1965 . Responsible for patient care in psychotherapy, for the teaching and knowledge transfer as well as for research and scientific research, the Psychotherapy Service has played an important role within the various IPQ services and groups and has also been included included in the debates of the "psi field"(1) throughout its fifty years of existence ${ }^{1}$.

History is presented as a scientific field of knowledge production that produces two main modalities of work, as shown by Mota and Schraiber ${ }^{2}$ : one modality called memorialist works, centered on the building of the historical narrative that aims to highlight the internal developments of a given field or object, as it reifies positive values and linear time advances, showing how practices, techniques and ideas occur while being marked by the notion of progress, and another modality characterized by its use of a theoretical and methodological matrix which aims to create conditions for other readings and interpretations of the historical facts, through the input of theories and concepts that can be related to the facts and their contexts.

This study is ruled by the latter notion of history presented above and aims to present a critical approach to the formation of the Psychotherapy Service of the IPQHCFMUSP. Through this analysis we can understand the articulation of our field of study with other fields and their social and historical context, allowing us to realize the undoubted social relationships that exist between knowledge and the society from which it emerges.

In that sense we will think of this history as a fundamental process for the development of the plurality of actions and discourses on mental health within the context of the IPQ, which is present in both the therapeutic actions offered to the community and also in academic and professional training. We argue that the maintenance of plurality offers a basis so that the transmission of knowledge and the exercise of clinical practice are not unique to a particular world view or to a given area of knowledge, which also expands the possibilities available for people seeking assistance ${ }^{3}$.

Similarly, it is necessary that we realize the complex nature of the attempt to organize a Psychotherapy Service within a psychiatric hospital in the era of ubiquitous psychotropic medications. History shows us that when we approach the field of psychotherapies we need to keep in mind the divergent and sometimes contradictory nature between practices and theories that might have the same name but are not thought nor even practiced similarly ${ }^{(2)}$ The testimony of Jorge Wohwey Ferreira Amaro ${ }^{(3)}$, the main agent involved in the formation of the Psychotherapy Service is a striking example of this situation when he said that one of his greatest motivations for creating the Service was the fact that virtually all the psychiatrists in the hospital did what he called "guesstherapy", that is, psychotherapies without theoretical or methodological references, based on the personal beliefs of each doctor, whose criteria were not based on solid knowledge, which already existed at that time. They viewed pshychotherapy as a "persuasive process" in which the professionals, through the personal relationship and the influence they can exercise, aimed to direct the decisions and actions of patients according to their own values and life principles.

Between the complexity and plurality of knowledge and practices, psychotherapy has been building a unique institutional space over time, whose knowledge is specific and particular, focusing on the uniqueness of the subjects, their anguish and their psychic development. History

\footnotetext{
(1) Psi field is an expression used to describe the set of professions that are most directly related to the psychological or mental issues of people, as techniques and practices and also as fields of knowledge. Psychiatry, psychoanalysis, psychology and psychotherapy are the four professions that make up the psi field.

(2) Elisabeth Roudinesco, a French historian and psychoanalyst, points out, for example, the existence of at least two hundred different lines of psychotherapy nowadays.

(3) Interviews conducted on 08/17/2013 and 10/18/2014 for producing a Master's thesis on the Formation of the Psychotherapy Service.
} 
shows us that such an endeavor is rarely easy, built in the backstage, without the spotlight of technological advance, with criticism and questions about the relevance of its paradigms, since attention to uniqueness does not always correspond to the much desired numbers and results expected by an increasingly corporate science. Nonetheless, Psychotherapy Service builds a pathway that cannot be overlooked $^{4}$.

\section{The psi field of São Paulo in the 60s: an overview}

A fast-growing city, with massive migratory movement and huge population growth yet lacking the necessary development of basic services; the capital of the state that vies with Rio de Janeiro for recognition as the country's most important city, whose mayor would become president in $1961^{5}$; a scenario of intense popular movements in the troubled early period of the $60 \mathrm{~s}$, which divided the country; head office of the University of São Paulo, whose student movements represented an important focus of resistance to the actions of the military coup: these are some elements of the complex city of São Paulo, whose importance in the Brazilian and even global psi field was in process of formation.

Although the formation of an urban middle class with access to knowledge in times of expansion of the country's University network were factors that contributed to the popularization of psychotherapy in the city, the fact that it was restricted to a small portion of the population, the one that could afford the costs of the treatments, caused psychotherapy to reach the population segments quite heterogeneously. Though little in the way of historical narration exists, we can understand the importance, of the Psychotherapy Service, since it was a free public service, in times prior even to the implementation of psychiatry ambulatory services that could meet the medical needs of the city's growing population.

In the 60 s the city of São Paulo already had a considerable psychiatric care network. The paradigmatic model of the old Asylum of the Hospital Juquery, widely portrayed and also studied, no longer represented the center of the psychiatric discussions of the city. We speak of a care network because there were already several psychiatric institutions among private clinics and psychiatric hospitals.
Moreover, since the 30s psychiatry departments were organized at the two major medical schools in the city, FMUSP and the Escola Paulista de Medicina (Paulista Medical School), both created in 1936 under the direction of Pacheco e Silva. In the early 60s the Psychiatry Service of the Hospital Público do Servidor Estadual (Public Hospital of the Gorvernment Employee) and in 1966 the Department of Psychiatry of the Santa Casa de Misericórdia de Sao Paulo (São Paulo Holy House of Mercy) were also organized.

Although the asylum model symbolized by the Juquery Hospital was suffering criticism and undergoing a transformation process, and with it, all psychiatric practice centered on hospital admissions was also thrown into question, the number of available ambulatories and ambulatory attendances were still in their early stages in the city. In addition to the institutions, the professionals also conducted their activities in their offices, routinely announced in the medical index of the city's leading newspapers.

At the same time and with prominent importance, the Brazilian Society of Psychoanalysis of São Paulo (Sociedade Brasileira de Psicanálise de São Paulo SBPSP), created officially in 1951, began gaining space and prestige. The SBPSP, the group led by the FMUSP psychiatrist Durval Marcondes and composed of Adelheid Lucy Koch, Darcy de Mendonça Uchoa, Flávio Rodrigues Dias, Frank Julien Philips and Virgínia Leone Bicudo, represented another important center of the Psi Field of São Paulo. Psychoanalysis and had reached the country in the 20s. It was present in medical, philosophy and education schools and was also part of the cultural scene of the city. As previously mentioned, issues concerning the authorization for people who were not physicians to become psychoanalysts churned the field, especially in the 40s and 50s. Psychoanalysis was not present only in the circle of psychoanalytic debate, but was also, though sometimes in a troubled way, an integral part of psychiatric discussions. São Paulo was about to become one of the major psychoanalytic centers of world, with a fellowship composed of more than 800 members today.

It is important to emphasize that psychoanalysis circulated in other institutional spaces and we highlight two among them: USP's Faculty of Philosophy, Science 
and Literature for its specialization courses in psychology already in the 30 s and 40 s and later, in the late 50 s through to the creation of the Durval Marcondes Psychological Clinic and the Institute of Psychology, the IPUSP itself; and the Sedes Sapientae institute, an important center for professional training and also for the transmission of psychoanalytic knowledge and other lines of psychotherapy.

\section{Plurality and complexity action in mental health}

If by the end of the 70s the Brazilian society discussed the matter of the Brazilian Psychiatric Reform ${ }^{(4)}$ through a comprehensive process which involved various sectors of society through scathing criticism of the asylum model which was predominant in the country, the 60 s can be thought of as the beginning, though small and limited, of this transformation process ${ }^{5}$. The technological changes in the psychiatric practice caused by the introduction of more effective drugs in association with the inclusion of psychological clinical practices, which were able to be introduced into in the psychiatric institutions, are factors that are also part of this slow and gradual process of transformation. Moreover, the failure of the asylum model itself, through the many accusations reported by the press ${ }^{6}$, cannot fail to be mentioned as one of the main factors that instigated this process of transformation of mental health practices in the country, even though the change is slow, problematic and very complex.

The field started to be increasingly seen as a complex field in which the interaction between different professionals would be the rule and not the exception. The notion of complexity in ways to approach different problems, as proposed by Edgar Morin ${ }^{7}$, starts making a lot of sense. He says:

Pertinent knowledge must confront complexity. Complexus means "woven together"; in fact, there is complexity when different elements are inseparable constituents of a whole (such as economic, political, social, psychological, emotional, mythical aspects), and there is an interactive, interdependent and inter-retroactive fabric between the object of knowledge and its context, the parts and the whole, the whole and the parts, the parts among each other. For this reason complexity is the combination between unity and multiplicity (p.34)

Interdependence and retroactivity are ways of thinking about the structural framework of pluralism and complexity that now underpin the discussions. It is no coincidence that we can observe, in the IPQ of the 60s, the implementation of different services that contributed to the increase of possibilities to approach mental health, such as functional neurosurgery, electroencephalography, social work, psychology and psychotherapy services. This articulation expands the professional categories involved in the whole process, categories which were previously restricted to staff, i.e. doctors, nurses and hospital security guards. It would be increasingly relevant to think about the action in mental health as a set of practices involving different fields, each one of them with their own specificities. Diagnoses and drug treatments developed by psychiatrists began to include reviews and psychological tests, as well as contributions from social workers. Likewise, referrals to care in individual or group psychotherapy for ambulatory patients or patients in the wards became a part of the hospital's routine, expanding the network of possibilities and therapeutic modalities.

The National Congress approved the project for the regulation of the profession of psychology, transformed into Law 4119 of August 27, 1962 ${ }^{8}$, which allowed psychologists to also practise clinically. In addition to the expansion of the network of professionals involved in mental health care, the chorus for the opening of the psi field was broadened, whether in the change in patient care under the direction of psychiatric institutions or in the greater possibility of access to training which was dominated at that time by psychoanalysis.

The matter of professional regulation has always been a complex topic in the psi field ${ }^{(5)}$. In the 60 s clinical

\footnotetext{
(4) Brasil. Ministério da Saúde (Brazilian Ministry of Health). Secretaria de Atenção à Saúde. DAPE. General Coordination of Mental Health. Psychiatric reform and mental health policy in Brazil. A document presented to the Regional Conference on Reform of the Mental Health Services: 15 years after Caracas. Brasília: OPS; November 2005.

(5) As an iconic example of this situation we can mention the First Latin American Mental Health Congress, held in 1954 during the fourth centenary of the city of São Paulo, under the responsibility of the former FMUSP Psychiatric Clinic directed by Professor Antônio Carlos Pacheco e Silva. Abrão, in the biography of Virgínia Bicudo, an important São Paulo psychoanalyst of that time, mentions the well known episode in which Virgínia Bicudo, Lygia Amaral and Judith Andreucci, non-medical psychoanalysts were accused of fraud because physicians did not accept the exercise of psychoanalysis by non-medical professionals.
} 
practice was exercised mainly by psychiatrists and psychoanalysts $^{(6)}$ (of whom many were physicians) in public or private institutions and also in private practice. Is worth mentioning that with the creation of the INPS in 1966 many private institutions have become a part of the care network, financed by the government. Moreover, some studies ${ }^{5,6,7}$ show that such growth in the health care network was not followed, in most cases, by an actual quality increase in the offered care, a point which was called into question in the context of the formation of the Service, i.e. being inserted in the scientific context of that time, organizing itself as a knowledge production and clinical practice field.

The orientation of the initiatives on thinking about mental health care through ambulatory patient care, with greater participation of other professionals whose different practices would add to the complexity of mental care and become the reference point of the implemented policies ${ }^{(7)}$. Although the formation of the Psychotherapy Service was not directly linked to any proper major mental health policy project, we can understand it within the scope of the above mentioned transformations. It is a concrete example in which the institutional organization enabled the better practice of a clinical activity, by promoting the possibility of scientific discussion, allowing ethical concerns regarding the activity itself and providing for the inclusion of issues arising from other fields within psychiatric training.

Nevertheless, even with such attempts, the changes that could be observed with the formation of the Service moved slowly. For example, a Medical Psychotherapy Service was created, performed by psychiatrists, with no other professional training requirements, precisely at the time in which psychologists were authorized to work clinically. This possibility was never mentioned in the Service context, which was restricted to psychiatrists. Even though it was inclusive and more complex, the issues surrounding the professional fields persisted.

\section{Psychodynamics and the relationship between psychoanalysis and psychiatry}

When discussing plurality and complexity notions as components of the historical process that allows both the formation of the Psychotherapy Service, and also the constitution of changes (which are not easy at all) in the psi field as a whole, it is important to highlight the fact that the first approach that occurred in the field was precisely the one which created a relationship between psychoanalysis and psychiatry. Despite the criticism and disagreements, it appears that psychoanalysis as a knowledge and practice field influenced the psychiatric field, also in its knowledge and practice, especially until the 80 s. Many psychiatrists sought training in psychoanalysis, which was part of the field's academic and scientific discussions, and studied closely the books and manuals of the time as well as the daily lives of the inhabitants of major Western cities; in Brazil, especially in Rio de Janeiro, São Paulo, Recife and Porto Alegre.

Clóvis Martins, an IPQ psychiatrist, editor of the Boletim da Clínica Psiquiátrica (Psychiatric Clinic Newsletter), the first scientific publication of the IPQ, published in April 1963 an article which helps us understand the situation of psychodynamics at that time. The article was based on a Formal Sitting in the newly founded Psychiatric Association of São Paulo and notes:

The sensed progress, rapid and revolutionary, removed Clinical Psychiatry from an system which is almost medieval when compared with the other sectors of medicine and, paradoxically, in a very short time this progress pushed it forward, giving it a cutting-edge science aspect and establishing a reverse situation: if previously it was kept in the limitation of an asylumbased care which was subservient to medicine, isolated in the asylums and neglected in scientific conclaves, now switches to the opposite pole; the psychodynamic interpretation invaded every field of medicine; a psychosomatic approach is now the major concern of all specialties and there is no medical science sector that does

(6) This is a controversial topic with a number of issues that transcend the limits of this article. Is worth remembering that Freud, the creator of psychoanalysis, proposed that non-medical professionals could also become psychoanalysts, provided that they were trained in psychoanalysis.

(7) On January 21, 1962, the o Estado de São Paulo newspaper publishes, in an article called Mental Illnesses: measures to mitigate the problem, that there were only three ambulatories in the state of São Paulo, two in the capital and one in Campinas. By the same time there were 150 official psychiatric hospitals (public and private) and 30 ambulatories throughout the country. Available from: http://acervo.estadao.com.br/ pagina/\#!/19620121-26609-nac-0022-999-22-not/busca/Hospitais 
not focus on psychogenesis research, seeking in it the first cause for disorders, which until recently was subject to a purely physical investigation (p.70) $)^{13}$.

As pointed out in the excerpt, psychodynamic interpretation invaded every field of medicine, and psychiatric with even greater intensity. Much of this statement is due to the huge connection between psychoanalysis and psychiatry in the United States, whose occurred in the mid-50s. The notion of psychodynamics arises precisely as a result of the alliance between psychoanalysis and the ideas of European psychoanalysts who went to the United States as refugees as a consequence of the war, with American psychiatrists ${ }^{(8)}$.

The alliance between psychoanalysis and psychiatry in the United States promoted a process that broadly conceived as an adaptation of psychoanalytic theories and techniques to the reality and needs of American psychiatry. Robert Wallrestein (1921-2014) psychoanalyst, former president of the International Psychoanalytic Association (IPA) and professor of the San Francisco Department of Psychiatry, while studying this process, said that most American psychiatrists of that time (the 50s and 60s) practiced what was known as psychodynamics: "different from psychoanalysis, but inextricably connected to it, establishing itself as the main vehicle of co-optation of American psychiatry by the psychoanalytic ideal" (p.29) ${ }^{9}$.

A fact that also helps us to prove this context is the strong presence of psychoanalytical concepts and terminology in the publication of the first Diagnostic and Statistical Manual of Mental Disorders, the DSM, in 1952, permeated by psychoanalytical notions. Dunker and Kyrillos Neto ${ }^{10}$ show us that until the publication of the DSM III, in 1980, psychoanalysis was present in the psychiatric field, whether in diagnostic formulation and, therefore, in the construction of psychiatric epistemology itself, or in the therapeutic aspects.

Finally published in 1980, the DSM-III has been considered a profound transformation in psychiatry. Presented as a non-theoretical and operational classification system of the major psychiatric syndromes, this manual changed the notion of psychiatric research and practice, as psychiatry now had a precise diagnostic system from the descriptive and terminological point of view and likely to provide support for empirical and experimental research (p.616) ${ }^{10}$.

The IPQ was heavily influenced by American ideas, whose psychiatrists would often travel and visit American institutions. It could be expected that the same initiatives observed in other countries were to be adopted by the IPQ, given the efforts for it to remain at the same level of other global institutions. This, among other factors, can help us understand not only the development of a psychotherapy service as a result of this approximation between psychiatry and psychoanalysis, but also the subsequent movements of distancing from psychoanalysis and openness to other schools of psychotherapy, from the late 80 s on.

\section{Working with groups}

The main influences in the $60 \mathrm{~s}$ for the psychotherapeutic practice in São Paulo were derived primarily from the American notions of psychodynamics, from psychoanalysis, via SBPSP and from the empirical psychiatric psychotherapeutic practice. The great demand for care, combined with possible changes in the classic psychoanalytic practices, in addition to the contributions that began to emerge from other schools (which would later gain real importance, such as psychodrama and analytical psychology) are the main elements which stimulated, also empirically, the beginning of group psychotherapy.

In 1960, for example, the Sociedade Paulista de Psicologia e Psicoterapia de Grupo (São Paulo Society of Group Psychology and Psychotherapy) was created, and chaired by Bernardo Blay Neto, a SBPSP psychiatrist and psychoanalyst. Its members were mostly psychoanalysts linked to the SBPSP. Some of them, such as Odilon Ferreira and Oscar Rezende de Lima, worked in the IPQ. Amaro ${ }^{(9)}$ informs us that it was necessary to build a field that

\footnotetext{
${ }^{(8)}$ According to Wallrestein, Adolf Meyer's psychobiological psychiatry, the growth of mental hygiene movements, the impact of progressive education under John Dewey's lead and other optimistic ideas such as the "home settlement movement" were the main points of the North American context of the creation of psychodynamic psychotherapy. European psychoanalysts fleeing war associated with the American psychiatrists, thus inserting themselves in psychiatric institutions, and also in universities, which allowed both an American development of psychoanalysis and adaptations to classic models that sought to handle the clinics at that time.

(9) Amaro JWF. Departamento de Psiquiatria da FMUSP. Depoimento pessoal, 2013.
} 
really met the institutional demands, which were already very high at that time. Thus, group care was privileged over individual care. The greater pressure to "meet the demand" when compared with the other issues involved in the process can be associated with the expansion of the psychiatric care network as mentioned above and make us face a critical perspective of pluralism ${ }^{7}$, which we present as a factor that favors the inclusion of the Psychotherapy Service.

Another example in the wake of the transformation processes that we can also mention is the work of Antônio Carlos Eva, a psychiatrist and psychoanalyst who developed a post-graduate work on therapeutic communities, whose main focus was teamwork.

Some psychiatrists who did not choose to be trained in psychoanalysis took an interest in psychodrama, which had just arrived in the country. The difficult and objectionable requirements for psychoanalytic turned many psychiatrists interested in additional training onto psychodrama. This was in addition to issues related to any innovations introduced by this school, as pointed out by Cesarino $^{12}$. With the formalization of the Psychotherapy Service, several care groups were formed, and even though at that time the learning of techniques and theories had a very strong pioneering nature in the sense of empiricism, as a gateway, Eva coordinated the convergence of psychiatrists and other therapeutic modalities.

\section{CONCLUSION}

In the $60 \mathrm{~s}$, the importance of the IPQ was confirmed as a clinical service and knowledge production center in psychiatry. This is a period in which the city population was growing steadily, with increased demands for service, not

\section{REFERENCES}

1. Leite Netto OF, Lotufo Neto F. Considerações sobre uma experiência peculiar: Psicoterapia na Faculdade de Medicina da Universidade de São Paulo e no Instituto de Psiquiatria do Hospital das Clínicas da Faculdade de Medicina da Universidade de São Paulo. Rev Bras Psicoter. 2012;14(2):529. Disponível em: http://rbp.celg.org.br/detalhe_artigo. asp?id $=90$.

2. Mota A, Schraiber LB. Medicina sob as lentes da história: reflexões teórico-metodológicas. Cien Saúde Coletiva. 2014;19(4):1085-93. http://dx.doi.org/10.1590/141381232014194.16832013 . always followed by proper qualification. The relationship between psychoanalysis and psychiatry was more evident in that period, mainly through the influence of the events in the United States. The field of mental health was initiating a movement for an expansion of therapeutic possibilities, whether through the advent of drugs the development of psychotherapeutic techniques that could be adjusted according to institutional work requirements. The Psychotherapy Service falls within the context of the IPQ's permeability to the rearrangements of that period, which were brought about through reformulations in the care offered to the population, especially to that portion that was excluded from access to the psychotherapies of the day, when very little was available outside the private scope of medical offices.

The same permeability that enabled the organization of a Service that could improve psychotherapy practice conditions, until then practiced loosely ("guesstherapy") initiated a process that, when analysed more closely, has a complexity that transcends the simple introduction of new work techniques. The slow and non-linear temporal passage of mental health care had in the $60 \mathrm{~s}$, in the context of the IPQ, a moment of great significance, and its follow-up can be observed in the magnitude of the importance of the current activities of the Service.

The contact psychiatrists had with psychotherapeutic practices contributed to both their professional development, which generated positive consequences for the IPQ and also for other institutions in the city, as well as the quality of care offered to patients. The 60 s were the embryonic period of this introduction, and the formation of the Psychotherapy Service exemplifies the possibilities for dialogue and coexistence between different fields of mental health.

3. de Almeida Filho N. Transdisciplinaridade e saúde coletiva. Cien Saúde Coletiva. 1997;11(1/2). Disponível em: http://www.hc.ufmg.br/gids/textos_seminarios/ transdisciplinaridade e saude coletiva.pdf.

4. Paulin LF, Turato ER. Antecedentes da reforma psiquiátrica no Brasil: as contradições dos anos 1970. Hist Cienc SaudeManguinhos. 2004;11(2):241-58. http://dx.doi.org/10.1590/ S0104-59702004000200002.

5. Markun P, Hamilton D. 1961: o Brasil entre a ditadura e a guerra civil. São Paulo: Benvirá; 2011. 
6. Berlinck MT, Magtaz AC, Teixeira M. A reforma psiquiátrica brasileira: perspectivas e problemas. Rev Latinoam Psicopatol Fundam. 2008;11(1):21-8. http://dx.doi.org/10.1590/S141547142008000100003 .

7. Morin E. Os sete saberes necessários à educação do futuro. Trad. Catarina Eleonora F. da Silva, Jeanne Sawaya. 11a ed. São Paulo: Cortez; 2006. Cap.3, p.51.

8. Lei $\mathrm{n}^{\circ} 4.119$, de 27 de agosto de 1962. Available from: http:// www.planalto.gov.br/ccivil_03/leis/1950-1969/L4119.htm.

9. Wallerstein R. Psicanálise e psicoterapia de orientação analítica: raízes históricas e situação atual. In: Eizerik CL, Aguiar RW, Schestatsky SS. Psicoterapia de orientação analítica. 3a ed. Porto Alegre: Artes Médicas; 2015. p.19-41.

10. Dunker CIL, Kyrillos Neto F. A crítica psicanalítica do
DSM-IV-breve história do casamento psicopatológico entre psicanálise e psiquiatria. Rev Latinoam Psicopatol Fundam. 2011;14(4):611-26. http://dx.doi.org/10.1590/S141547142011000400003 .

11. Goulart MSB. A construção da mudança nas instituições sociais: a reforma psiquiátrica. Pesq Práticas Psicossociais (São João Del Rey). 2006;1(1):1-19. Available from: http:// www.ufsj.edu.br/portal-repositorio/File/revistalapip/A Construcao_da_Mudanca_nas_Instituicoes_Sociais..._MSB_Goulart.pdf.

12. Cesarino AC. Brasil 70: psicodrama antes e depois. Grupos: a proposta do psicodrama. São Paulo: Ágora; 1999. p.35-48.

13. Martins C. Associação Psiquiátrica de São Paulo. Bol Clin Psiquiatrica. 1963;2:70. 